\title{
Cyanidin 3-glycoside induced apoptosis in MCF-7 breast cancer cell line
}

Seyed Abbas Mirmalek ${ }^{1}$, Sholeh Faraji², Sanaz Ranjbaran², Hoda Aryan³ ${ }^{3}$ Hamid Zaferani Arani², Ehsan Jangholi², Hadi Zare Marzouni ${ }^{4}$, Seyed Alireza Salimi-Tabatabaee ${ }^{2}$

\author{
${ }^{1}$ Department of Surgery, Tehran Medical Sciences, Islamic Azad University, Tehran, \\ Iran \\ ${ }^{2}$ Young Researchers and Elite Club, Tehran Medical Sciences, Islamic Azad University, \\ Tehran, Iran \\ ${ }^{3}$ Department of Internal Medicine, Semnan University of Medical Sciences, Semnan, \\ Iran \\ ${ }^{4}$ Qaen School of Nursing and Midwifery, Birjand University of Medical Sciences, \\ Birjand, Iran
}

Submitted: 16.05 .2019

Accepted: 14.10 .2019

Arch Med Sci

DOI: https://doi.org/10.5114/aoms.2020.93789

Copyright $\odot 2020$ Termedia \& Banach

\begin{abstract}
Introduction: Breast cancer is the major leading cause of death from cancer among women. Given the drug resistance seen during the treatment of this disease, it is very important to identify new therapies and new anticancer drugs. Some studies indicate the cytotoxic effects of cyanidin 3-glycoside (C3G). Therefore, this study aims to evaluate the anticancer effect of C3G in the treatment of the MCF-7 cell line.

Material and methods: In this study, the MCF-7 cell line was treated with different concentrations of C3G for 24 and $48 \mathrm{~h}$. Assessment of cell death was performed by MTT assay. The cell apoptosis rate was measured using an Annexin $\mathrm{V} /$ propidium iodide assay through flow cytometry. The expression levels of p53, Bax, Caspase3, CYP1, CYP2, and BCl2 genes were evaluated using polymerase chain reaction, and Western blotting was performed for CYP1 to confirm the results.

Results: Our findings showed that $\mathrm{C} 3 \mathrm{G}$ has dose-dependent cytotoxic effects on the MCF-7 cell line. According to flow cytometry results, the apoptosis of the cells $24 \mathrm{~h}$ after exposure to C3G was more than 51.5\%. Moreover, after $24 \mathrm{~h}$ of exposure to the half-maximal inhibitory concentration of C3G, the expression of $p 53, B a x$, Caspase 3, CYP1, and CYP2 genes increased, and the expression of $B C l 2$ gene decreased. The Western blotting showed that CYP1 protein increased 2 -fold compared to the control sample.

Conclusion: The results of this study demonstrated that C3G has apoptotic and cytotoxic effects on breast cancer cells. Therefore, it is likely that this substance could be a suitable option for cancer therapy.
\end{abstract}

Key words: cyanidin 3-glycoside, breast cancer, anti-proliferative, herbal.

\section{Introduction}

Breast cancer $(\mathrm{BC})$ is considered the most common malignancy and one of the leading causes of death in women throughout the world [1]. While effective drugs such as tamoxifen and raloxifene, or anti-tumor effects of anastrozole along with radiation therapy have saved the lives of many affected women over the last 30 years, several disadvantages of these drugs, such as the relapse of disease due to metastasis a few

\author{
Corresponding author: \\ Seyed Alireza Salimi- \\ Tabatabaee \\ Young Researchers \\ and Elite Club \\ Tehran Medical Sciences \\ Islamic Azad University \\ Tehran, Iran \\ E-mail: sartmed@gmail.com
}


months after treatment - especially during chemotherapy - the negative effects of these drugs on the metabolism of glucocorticoids, and the risks of chemotherapy as well as complications of cytotoxic agents have limited the use of these therapeutic approaches [2-4].

One of the major restrictions of anticancer drugs is the resistance of cancerous cells to the drug, which might be caused by intrinsic resistance of the tumor to the drug, or acquired resistance during chemotherapy, and acting in such a way that resistant cells are selected among the tumoral cells, so the process of treatment becomes more difficult with increasing resistance of cells $[4,5]$.

Breast cancer, similar to other cancers, is caused by mutation, activation or strengthening of tumor-suppressing genes and proto-oncogenes as well as the loss of control of the cell cycle (proliferation more than inhibition) and cell survival (apoptosis less than normal cells). Given what was stated above, one of the new therapies is the use of herbal medicines, which can induce apoptosis in malignant cells [6-8].

Nowadays, herbal medicines have been considered due to the possible lack of side effects with up to date data, compared to chemical drugs [9]. Herbal medicines have been used in the treatment of cancers over the last 3500 years. One of the most important functions of anticancer medicines is the induction of apoptosis, which causes the death of cancer cells. Nowadays, many herbal compounds with different biological effects have been isolated and introduced in modern medicine, which are effective in the treatment of various cancers [10].

In this regard, the research on flavonoids has increasingly grown over the recent years due to various biological activities of these molecules [11]. Polyphenol compounds have anti-proliferative effects and stimulate apoptosis in cancerous cells [11-13]. Molecular studies conducted on phenolic compounds extracted from herbs and cancer cells have revealed that these compounds could stimulate programmed cell death in cancerous cells by increasing the intracellular calcium concentration, leading to reduced mass and increased probability of clinical improvement in these patients [14].

Anthocyanins are members of the flavonoids, a glycone form of which is called anthocyanidins, divided into different types based on the number and position of the hydroxyl and methoxyl substituent groups in their structure [15-17]. The biological activity of anthocyanins or anthocyanin-rich foods can be at various levels, including prevention of cardiovascular disease, anticancer activity, beneficial effects in diabetes (prevention of glucose uptake and protective effect on pancreatic cells), protective effect against hepatic damage, protective effects and recovery in abdominal inflammation, positive effects on vision, anti-bacterial, antiviral activity, and effects on nervous system disease $[15,16,18]$. Cyanidin 3-glycoside (C3G) is one of the most important anthocyanin components that is found in many plants and fruits, e.g., cherries, olives, and grapes [15]. Also, some studies indicated the antioxidative [17], anti-proliferative (e.g., glioblastoma) [11], and anti-inflammatory [16] effects of C3G. However, there is no evidence that revealed the possible apoptosis effect of C3G on BC cell lines. As a result, investigating the effect of these compounds on cancerous cells seems to be essential. Thus, this study aimed to evaluate the anticancer effect of C3G, as one of the most important anthocyanins, on the MCF-7 BC cell line.

\section{Material and methods}

\section{Materials and reagents}

The MCF-7 cell line was obtained from the Pasteur Institute of Iran. To culture these cells, high glucose Dulbecco's Modified Eagle Medium (DMEM) supplemented with 10\% fetal bovine serum (FBS) plus $100 \mathrm{mg} / \mathrm{ml}$ streptomycin and $100 \mathrm{U} / \mathrm{ml}$ penicillin (all from Gibco, USA) were used. The medium was replaced with a fresh one every four days. C3G and 3-[4,5-dimethyl-2-thiazolyl]-2,5-diphenyl-2-tetrazolium bromide (MTT) assay kits were purchased from Sigma Aldrich (USA). The Annexin V/Propidium lodide (Annexin $\mathrm{V} / \mathrm{PI}$ ) apoptosis assay kit was obtained from Roche (Switzerland). Other reagents used in this study were purchased from Sigma Aldrich (Germany).

\section{MTT assay}

To investigate the half-maximal inhibitory concentration (IC50) dose of C3G on MCF-7 cells, the MTT assay was performed. To accomplish this test, 8000 and 6000 cells were seeded in each well of 96-well plates for 24 and 48 h MTT assay, respectively. After $24 \mathrm{~h}$ of seeding, these cells were treated with concentration ranges of C3G, for 24 and $48 \mathrm{~h}$. After this time was over, the MTT powder was added to each well based on the manufacturer's instructions. After $5 \mathrm{~h}$, formazan crystals appeared. The above media were disposed of, and the sediments were dissolved in $200 \mu$ l of dimethyl sulfoxide. The resulting purple solutions' absorptions were determined at $570 \mathrm{~nm}$ by a Biotek ELX800 microplate reader (USA).

\section{Apoptosis assay}

To confirm C3G-induces apoptosis in MCF7 cells, these cells were treated with $110 \mu \mathrm{g} / \mathrm{ml}$ of this substance and after $24 \mathrm{~h}$, flow cytometry was performed with the Annexin V/PI kit precisely according to the same protocol from the kit's manual. 


\section{Real-time polymerase chain reaction}

To determine whether treatment of MCF-7 cells with C3G affects the mRNA expression level of important genes in apoptosis and/or oxidation pathways, after treatment of these cells with an IC50 dose of C3G for $24 \mathrm{~h}$, total RNA was extracted utilizing TRIzol (Invitrogen) reagent. cDNA was synthesized by Takara cDNA synthesis kit (Japan) for the same amount of RNA from treated and/or control untreated samples. Primers were designed to specifically amplify cDNAs from p53, Bax, Caspase3, $B C l 2, C Y P 1$, and CYP2 (Table I). The program that was used to perform real-time polymerase chain reaction (PCR) with Rotor-Gene Q 5 plex Qiagen (Germany) was as follows: 1 . Holding stage: $95^{\circ} \mathrm{C} / 5 \mathrm{~min} .2$. Cycling stage: denaturing step; $95^{\circ} \mathrm{C} / 15 \mathrm{~s}$, followed by annealing step $60^{\circ} \mathrm{C} / 30 \mathrm{~s}$, amplification step $72^{\circ} \mathrm{C} / 20 \mathrm{~s}$ (number of cycles: 40 ). 3. Melt curve stage.

\section{Western blot}

CYP1 protein expression level was investigated in different samples including $24 \mathrm{~h}$ IC50-treated cells and untreated control MCF-7 cells by western blotting. Cells from different samples were lysed, and the same amount of protein from each sample was used for the test. By utilizing $10 \%$ sodium dodecyl sulfate-polyacrylamide gel electrophoresis (SDS-PAGE), proteins were separated and then transferred to nitrocellulose membranes. The membranes were incubated with $5 \%$ nonfat milk at room temperature/ $1 \mathrm{~h}$ for blocking. Membranes were then incubated with primary rabbit polyclonal antibody against CYP1 protein (Abcam, UK) overnight at $4^{\circ} \mathrm{C}$ (rabbit monoclonal antibody against $\beta$-actin used as control). Subsequently, membranes were washed with Tris-buffered saline containing Tween-20 and incubated with secondary antibodies Goat Anti-Rabbit IgG H\&L (HRP, Abcam, UK). The immunocomplexes were visualized with an ImmobiIon Western Chemiluminescent HRP substrate (Millipore, USA). The bonds that became visible were quantified by Image J (Fiji) software and normalized with $\beta$-actin protein bonds from each sample.

\section{Statistical analysis}

All results were expressed as mean \pm standard deviations (SD). Also, Student's t-test, analysis of variance, and Bonferroni's tests were applied. Data were analyzed using GraphPad Prism software (version 6.01, GraphPad, La Jolla, CA). The significance level was set at $p<0.05$.

\section{Results}

\section{Defining IC50 dose}

MTT assay demonstrated that C3G caused a significant decrease $(p \leq 0.01)$ in viability or
Table I. Sequences of real-time PCR primers, amplification reactions, and conditions for evaluation of the relative expression

\begin{tabular}{|llc|}
\hline $\begin{array}{l}\text { Gene } \\
\text { name }\end{array}$ & Primers sequences (5'-3') & $\begin{array}{c}\text { Ampli- } \\
\text { con }\end{array}$ \\
\hline GAPDH & $\begin{array}{l}\text { F: AAGTTCAACGGCACAGTCAAGG } \\
\text { R: CATACTCAGCACCAGCATCACC }\end{array}$ & $121 \mathrm{bp}$ \\
\hline p53 & $\begin{array}{l}\text { F: TCCTCAGCATCTTATCCGAGTG } \\
\text { R: AGGACAGGCACAAACACGCACC }\end{array}$ & $265 \mathrm{bp}$ \\
\hline Bax & F: CCAAGAAGCTGAGCGAGTGT & $156 \mathrm{bp}$ \\
& R: CCCAGTTGAAGTGCCGTCT \\
\hline Bcl2 & F: TCTTTGAGTTCGGTGGGGTC & $153 \mathrm{bp}$ \\
& R: GTTCCACAAAGGCATCCCAG \\
\hline Caspase3 & $\begin{array}{l}\text { F: GGCGCTCTGGTTTTCGTTAAT } \\
\text { R: CGACATCTGTACCAGACCGAG }\end{array}$ \\
\hline CYP1 & $\begin{array}{l}\text { F: CCGACACTCTTCCTTCGTCC } \\
\text { R: ATGGTTGATCTGCCACTGGTT }\end{array}$ \\
\hline CYP2 & F: GTACAACTCCCTCATGAAGATCAGT & $205 \mathrm{bp}$ \\
& R: CTCCCCGTTGCTGAATACCA & \\
\hline
\end{tabular}

proliferation of the MCF-7 cell line comparing to the untreated cells $(\mathrm{IC} 50=110 \mu \mathrm{g} / \mathrm{ml})$; cellular viability of the treated MCF-7 cells was reduced to $50 \%$ at a concentration of $110 \mu \mathrm{g} / \mathrm{ml}$ of C3G in comparison to the controls after $24 \mathrm{~h}$. Also, the MTT test revealed that treatment of cells with $60 \mu \mathrm{g} / \mathrm{ml}$ of this substance results in about $50 \%$ death after $48 \mathrm{~h}$ (Figure 1).

\section{C3G induced apoptosis in MCF-7 cells}

Annexin V/PI flow cytometry was performed to quantify cells that underwent apoptosis after C3G treatment. Our results confirmed that the type of cellular death that was induced in MCF-7 cells after $24 \mathrm{~h}$ with $110 \mu \mathrm{g} / \mathrm{ml}$ of C3G was apoptosis. This treatment induced $51.5 \%$ apoptosis in these cells (Figure 2).

\section{C3G increased proapoptotic and decreased anti-apoptotic mRNA expression}

C3G induced upregulation of pro-apoptotic genes including p53, Bax, and Caspase 3, and downregulation of the anti-apoptotic gene $\mathrm{BCl} 2$ at mRNA level. Moreover, this treatment caused upregulation of CYP1 and CYP2 mRNAs (Figure 3).

\section{Effect of C3G on antioxidant protein level in MCF-7}

Western blot analysis was used to assess the underlying mechanism for induction of apoptosis. Hence, CYP1 level and actin protein as an internal control were measured. MCF-7 cells that were treated with $110 \mu \mathrm{g} / \mathrm{ml}$ of $\mathrm{C} 3 \mathrm{G}$ for $24 \mathrm{~h}$ expressed CYP1 protein about 2-fold more than the untreated control cells (Figure 4). This result indicated that $\mathrm{C} 3 \mathrm{G}$ treatment could enhance the 
A

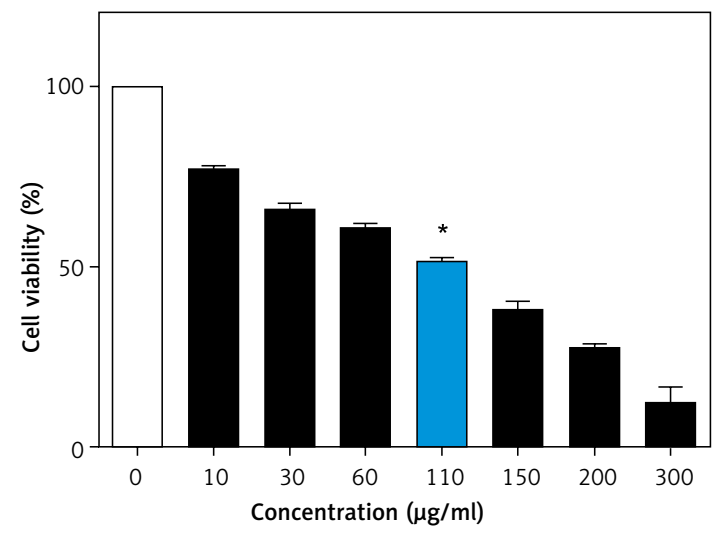

B

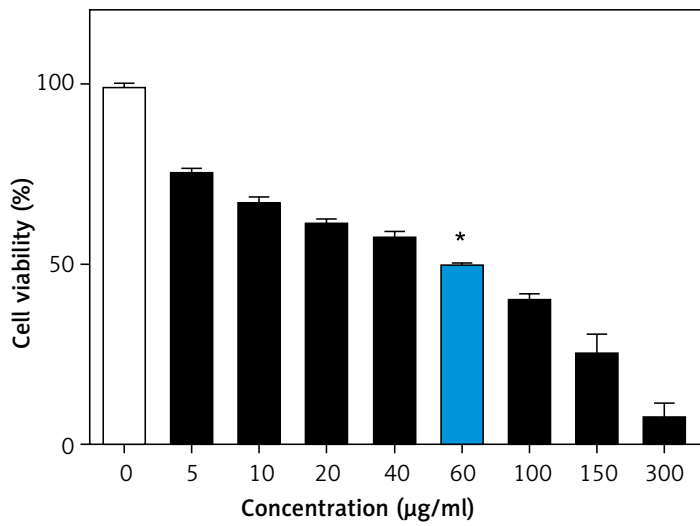

Figure 1. MTT assay results indicated that treatment of MCF-7 cells with $110 \mu \mathrm{g} / \mathrm{ml}$ of C3G for $24 \mathrm{~h}$ (A) induces about $50 \%$ cellular death. Also, treatment of these cells with $60 \mu \mathrm{g} / \mathrm{ml}$ of C3G caused $50 \%$ cellular death after $48 \mathrm{~h}$ (B)

${ }^{*} p \leq 0.01$ vs. control (untreated cells).

cytostatic effect of this compound on the MCF-7 cell line.

\section{Discussion}

$B C$ is one of the most common cancers throughout of world, which leads to considerable annual mortality $[19,20]$. It can have a genetic and/or environmental origin [21, 22]. Surgery, chemotherapy, and radiotherapy are among the methods used commonly to treat BC [22]. Resistance to treatment is one of the most important problems in using these therapeutic methods [23].

Moreover, each of these treatments has several complications. Thus, selecting alternative therapeutic methods with the fewest complications is crucial $[4,19,24]$. While new genes and enzymes involved in inhibition or pathogenesis of cancer have been recognized, and studies have been con-

A

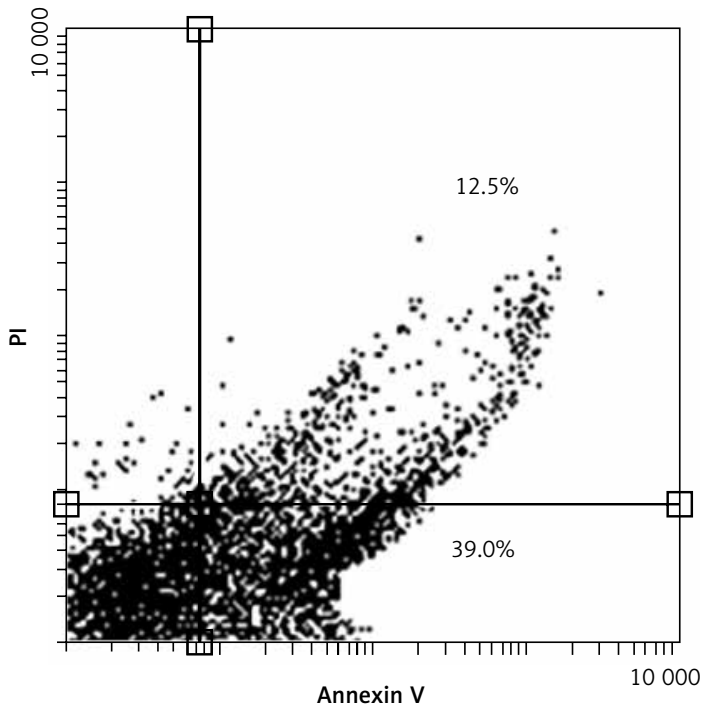

ducted on these new treatments, much attention has been paid to finding new anticancer compounds with herbal origin over the recent years $[21,22,24]$. One of the functions of anticancer medicines is the induction of apoptosis, leading to the death of cancerous cells.

Epidemiological evidence suggests that polyphenol compounds can be considered as anticancer agents [17, 25, 26]. C3G, as a polyphenol agent, has an herbal origin and it is an active ingredient of some fruits. Some studies have evaluated the anticancer effects of C3G and have reported promising results $[15,17]$. Anticancer effects of C3G have been shown in various forms of in vitro and in vivo experiments $[27,28]$. The mechanism of action of C3G in the treatment of cancer cells has not been clarified, but this substance is believed to be involved in death and several biochemical

B

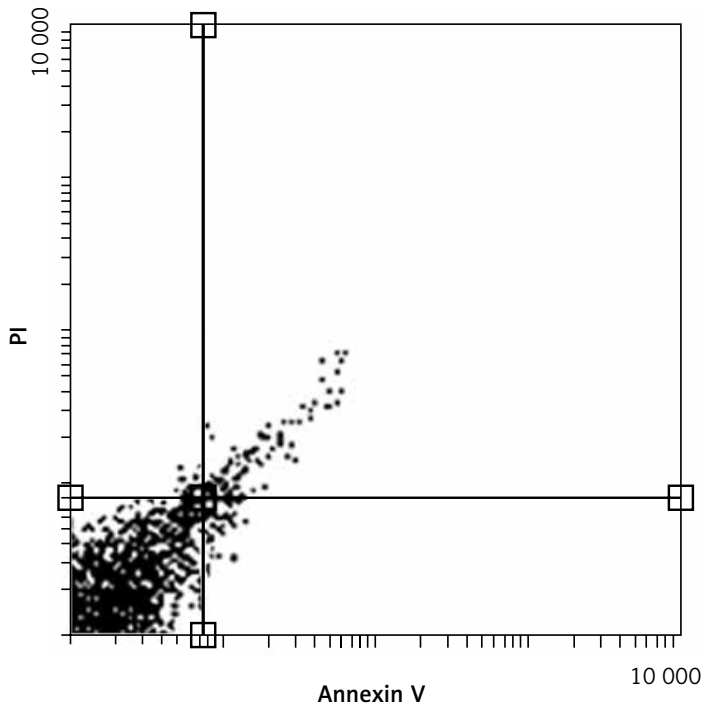

Figure 2. Flow cytometry for Annexin V/PI revealed that the type of cellular death induced after treatment of MCF-7 cells with IC50 of C3G for $24 \mathrm{~h}$ was apoptosis. Indeed, this treatment induced $51.5 \%$ apoptosis (A, right upper and lower quadrants). Quadrants are normalized with the control sample (B) 
A

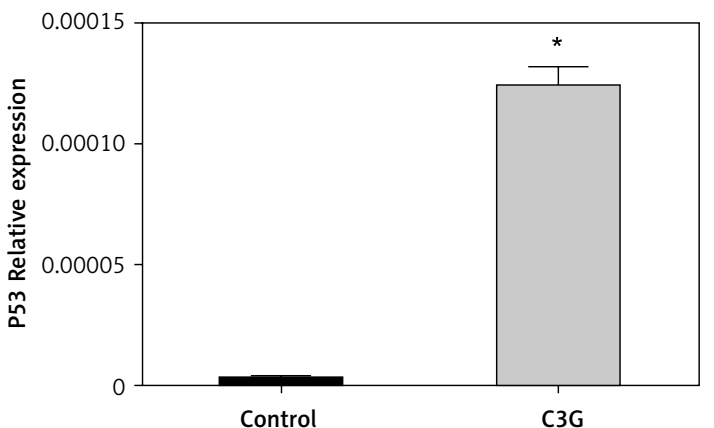

C

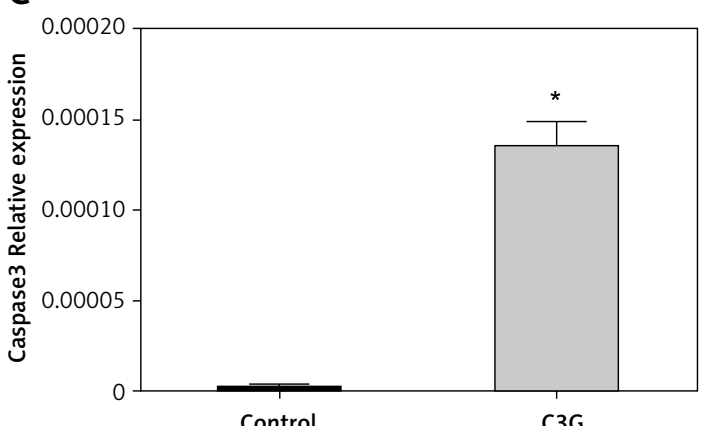

$\mathrm{E}$

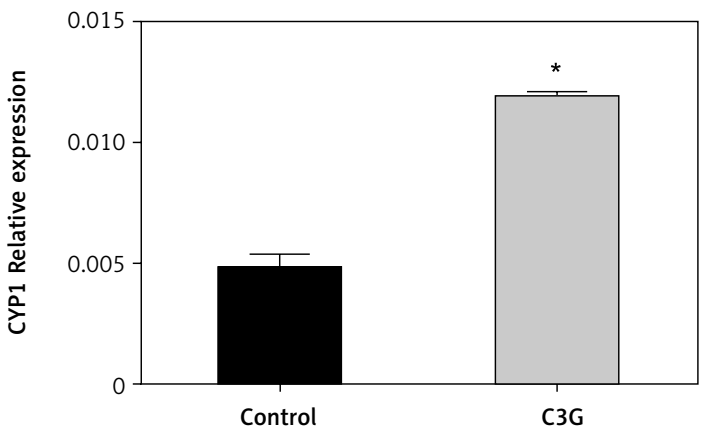

B

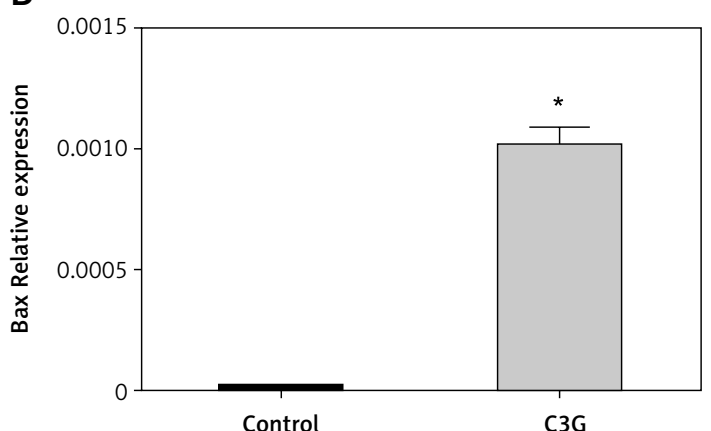

D

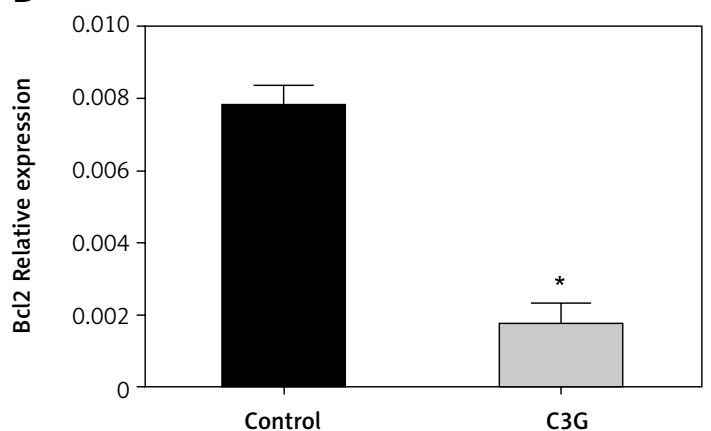

$\mathbf{F}$

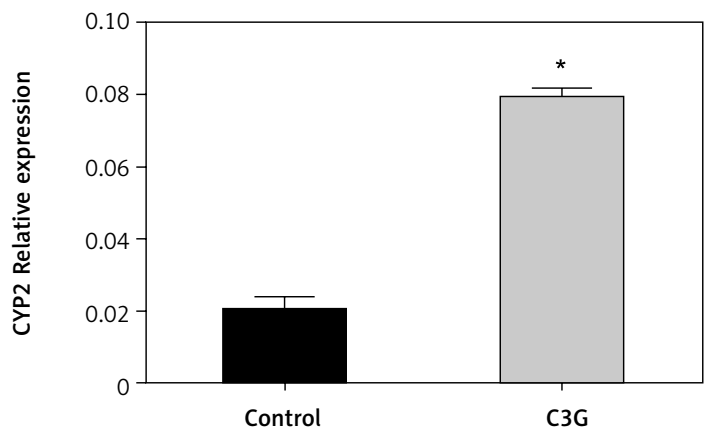

Figure 3. Real-time PCR data performed for essential genes in apoptosis and oxidation pathways. After treatment of MCF-7 cells with IC50 of C3G for $24 \mathrm{~h}$, the expression of p53, Bax, and Caspase 3 increased at mRNA level. Nevertheless, the mRNA expression level of $\mathrm{BCl} 2$ decreased. After this treatment, the expression of antioxidant genes (CYP1 and CYP2) increased significantly

${ }^{*} p \leq 0.01$ vs. control (untreated cells).

pathways of cells. C3G at low concentrations has antimicrobial properties without side effects. This compound has the roles of cell killing and inhibition against cancer-producing chemical agents in various cell lines. Some studies have reported its effect on the treatment of some of the most effective cancer cases [25]. Evaluation of DNA changes through the Comet assay shows the C3G effectiveness on some types of prostate cancer cell lines $[25,29]$. The results of current research revealed that C3G has a significant cytotoxicity effect on the MCF-7 cell line so that IC50 for this extract was $110 \mu \mathrm{g} / \mathrm{ml}$ and $60 \mu \mathrm{g} / \mathrm{ml}$ after 24 and $48 \mathrm{~h}$ of exposure, respectively. The results suggest the high cytotoxicity effect of C3G on the MCF-7 cell line.

Also, flow cytometry was used to evaluate the rate of apoptosis and assess the cytotoxicity in- duced and confirm the results by exposure to C3G on the MCF-7 BC cell line. Also, by measuring the level of expression of $\mathrm{Bax}, \mathrm{BCl} 2, \mathrm{p} 53$, Caspase 3 , CYP1, and CYP2 mRNA genes, as genes involved in cell survival and death, and genes related to oxidative status, real-time PCR was used. The results of the accuracy of CYP1 protein production assessment were also determined by the Western blotting method. Our findings suggest that more than $52 \%$ of apoptosis was induced as a result of 24-hour exposure to C3G with the MCF-7 cell line. The results also show an increase in the expression of pro-apoptotic (Bax, p53, and Caspase3) and antioxidant (CYP1 and CYP2) genes, and reduction of cell survival expression gene $(B C l 2)$. Confirmation of the results was performed by Western blotting on the CYP1 gene, and the accuracy of the results 
A

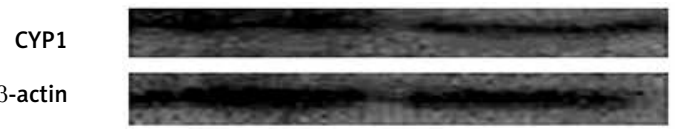

B

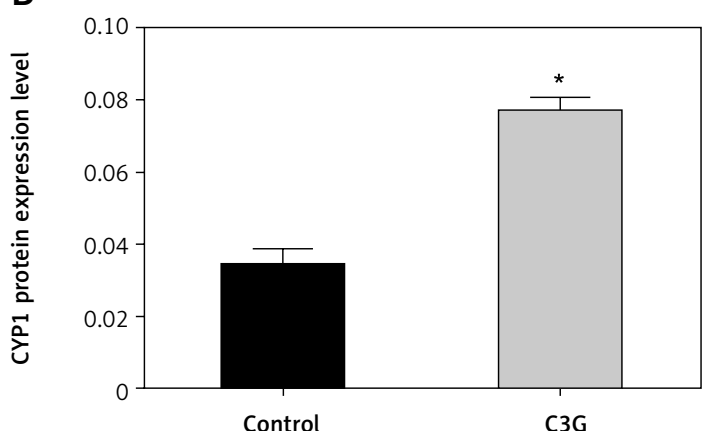

Figure 4. Western blot results for CYP1 protein showed that after the treatment of MCF-7 cells with the IC50 of C3G for $24 \mathrm{~h}$, the expression of CYP1 protein increased 2-fold compared to the control sample. (A - Western blot results, and $\mathbf{B}$ - quantification of western blot results)

${ }^{*} p \leq 0.05$ vs. control (untreated cells).

was confirmed, so that the value of CYP1 protein production increased by 2 -fold.

Previous studies revealed that treatment of cancer cells with C3G proves pro-apoptotic effects through activating Caspase 3 and increasing the expression of $p 21$ protein [25]. C3G causes caspase-independent and caspase-dependent cell death. Also, C3G causes a significant increase in the expression of $p 21$, as a negative regulator of cells, only in cancer cells [25]. The study conducted by Chen et al. showed that the presence of $50 \mu \mathrm{M}$ of C3G could induce apoptosis in lymphocytes due to changes in apoptotic protein levels (BCl2, Bax, and Caspase-3). C3G also reduces the expression of mutated $p 21$ and increases the $B a x / B C l 2$ ratio and activation of Caspase 3 to cause apoptosis [28]. In a study conducted by Renis et al., anti-proliferative and pro-differentiating properties of C3G were examined. They found that this substance could be considered as a preventative agent for cancer [30].

Data of the study conducted by Pace et al. [26] show that C3G causes apoptosis in BC cells (MDA-MB-453). For this reason, it can be considered as a potential anticancer agent. These results indicate that $\mathrm{C} 3 \mathrm{G}$ prevents the proliferation and growth of cancer cells both in vitro and in vivo conditions, and suggests the inhibition of tumor development [27]. Also, the results of the study conducted by Sorrenti et al. [25] showed that C3G, the most abundant anthocyanin in the diet, might be a new and effective compound in reducing carcinogenesis, with both anti-proliferative and pro-differentiating properties. These results and a review of similar studies suggest that C3G induces apoptosis by increasing the expression of cell death-inducing genes and preventing cell division through the expression of cell survival genes. It seems that the anti-oxidative proportion of C3G is a probable mechanism that could attenuate cell proliferation of MCF-7 cells. However, its mechanism of action has not yet been clarified.
There are some limitations in the present study. We investigated only the cytotoxic effect of C3G on the MCF-7 cell line; however, no comparison was performed between C3G and some other agents, e.g., doxorubicin or cisplatin. Also, only one BC cell line (MCF-7) was applied, and other BC cell lines, e.g., MDA-MB-231, were not tested.

In conclusion, the results of this study suggest that C3G, as a cytotoxic substance, induces cell death in MCF-7 BC line cells. With proper anticancer effects, this substance could be recommended as an appropriate alternative for the treatment of this disease. However, further studies are necessary to determine the clinical applications and specific mechanisms underlying the beneficial properties of C3G that might also prove to be targets of other anticancer therapies with future therapeutic potential.

\section{Conflict of interest}

The authors declare no conflict of interest.

\section{References}

1. Marzouni HZ, Lavasani Z, Shalilian M, et al. Women's awareness and attitude toward breast self-examination in dezful city, Iran, 2013. Iran Red Crescent Med J 2015; 17: e17829.

2. Mirmalek SA, Elhamkani F, Tabatabaee SA, et al. Introduction of HER-2 and a short review on its role in prognosis and treatment of breast cancer. Galen Med J 2014; 3: 132-44.

3. Mirmalek SA, Jangholi E, Jafari M, et al. Comparison of in vitro cytotoxicity and apoptogenic activity of magnesium chloride and cisplatin as conventional chemotherapeutic agents in the MCF-7 cell line. Asian Pac J Cancer Prev 2016; 17 (S3): 131.

4. Shahzamani K, Zare Marzouni H, Tarkhan F, Lashgarian H. A study of mechanism and Rate of PC12 Cancer Cell Destruction Induced by Lysine-Coated Gold Nanoparticle. Journal of Babol University of Medical Sciences 2016; 18: 41-7. 
5. Lipinska N, Romaniuk A, Paszel-Jaworska A, Toton E, Kopczynski P, Rubis B. Telomerase and drug resistance in cancer. Cell Mol Life Sci 2017; 74: 4121-32.

6. Mirmalek SA, Azizi MA, Jangholi E, et al. Cytotoxic and apoptogenic effect of hypericin, the bioactive component of Hypericum perforatum on the MCF-7 human breast cancer cell line. Cancer Cell Int 2016; 16: 3.

7. Aalipour E, Jangholi E. Prognosis and predictive factors related to breast cancer. Galen Med J 2016; 5: 45-8.

8. Abbasi GN, Radmansouri M, Ghiasvand S, et al. Hypericin Induces Apoptosis in MDA-MB-175-VII Cells in Lower Dose Compared to MDA-MB-231. Arch Iran Med 2018; 21: 387.

9. Kooti W, Servatyari K, Behzadifar M, et al. Effective medicinal plant in cancer treatment, part 2: review study. J Evid Based Complementary Altern Med 2017; 22: 982-95

10. Mashayekhi K, Zare Marzouni H. Curcumin (extracted from tumeric) and its therapeutic effects. Jorjani Biomed J 2017; 4: 1-20.

11. Hosseini MM, Karimi A, Behroozaghdam M, et al. Cytotoxic and apoptogenic effects of cyanidin-3-glucoside on the glioblastoma cell line. World Neurosurg 2017; 108: 94-100.

12. Aryan $\mathrm{H}$. The role of herbal medicine as anti-cancer medicine: from the claim to truth. Galen Med J 2018, 7: e1179.

13. Cassiem W, de Kock M. The anti-proliferative effect of apricot and peach kernel extracts on human colon cancer cells in vitro. BMC Complement Altern Med 2019; 19: 32.

14. Budijanto S. Pengembangan bekatul sebagai pangan fungsional: peluang, hambatan, dan tantangan. Jurnal Pangan 2017; 26: 167-76.

15. Lin BW, Gong CC, Song HF, Cui YY. Effects of anthocyanins on the prevention and treatment of cancer. $\mathrm{Br}$ J Pharmacol 2017; 174: 1226-43.

16. Venancio VP, Cipriano PA, Kim H, Antunes LM, Talcott ST, Mertens-Talcott SU. Cocoplum (Chrysobalanus icaco L.) anthocyanins exert anti-inflammatory activity in human colon cancer and non-malignant colon cells. Food Funct 2017; 8: 307-14.

17. Grosso G, Godos J, Lamuela-Raventos R, et al. A compre hensive meta-analysis on dietary flavonoid and lignan intake and cancer risk: level of evidence and limitations. Mol Nutr Food Res 2017; 61: 1600930.

18. Obakan-Yerlikaya P, Arisan ED, Coker-Gurkan A, Palavan-Unsal N. Breast Cancer and Flavonoids as Treat ment Strategy. Breast Cancer-From Biology to Medicine. InTech 2017.

19. Parsa Y, Mirmalek SA, Kani FE, et al. A review of the clinical implications of breast cancer biology. Electronic Physician 2016; 8: 2416.

20. Parks R, Derks M, Bastiaannet E, Cheung K. Breast cancer epidemiology. Breast Cancer Management for Surgeons. Springer 2018; 19-29.

21. Saburi E, Tavakol-Afshari J, Biglari S, Mortazavi Y. Is $\alpha$-N-acetylgalactosaminidase the key to curing cancer? A mini-review and hypothesis. J Buon 2017; 22: 1372-7.

22. Saburi E, Tavakolafshari J, Mortazavi Y, Biglari A, Mirzaei SA, Nadri S. shRNA-mediated downregulation of $\alpha$-N-Acetylgalactosaminidase inhibits migration and invasion of cancer cell lines. Iran J Basic Med Sci 2017; 20: 1021.

23. Marzouni HZ, Tarkhan F, Aidun A, et al. Cytotoxic effects of coated gold nanoparticles on pc12 cancer cell. Galen Med J 2018; 7: e1110.
24. Saburi E, Saburi A, Ghanei M. Promising role for Gc-MAF in cancer immunotherapy: from bench to bedside. Caspian J Intern Med 2017; 8: 228.

25. Sorrenti V, Vanella L, Acquaviva R, Cardile V, Giofrè S, Di Giacomo C. Cyanidin induces apoptosis and differentiation in prostate cancer cells. Int J Oncol 2015; 47: 1303-10.

26. Pace E, Jiang Y, Clemens A, Crossman T, Rupasinghe $H$. Impact of thermal degradation of cyanidin-3-O-glucoside of haskap berry on cytotoxicity of hepatocellular carcinoma HepG2 and breast cancer MDA-MB-231 cells. Antioxidants (Basel) 2018; 7: 24.

27. Cho $E, Y$ Chung $E$, Jang $\mathrm{H}-\mathrm{Y}$, et al. Anti-cancer Effect of Cyanidin-3-glucoside from Mulberry via Caspase-3 Cleavage and DNA Fragmentation in vitro and in vivo. Anticancer Agents Med Chem 2017; 17: 1519-25.

28. Chen M, Zhao Z, Yu S. Cytotoxicity and apoptotic effects of polyphenols from sugar beet molasses on colon carcinoma cells in vitro. Int J Mol Sci 2016; 17: 993.

29. Alimirah F, Chen J, Basrawala Z, Xin H, Choubey D. DU-145 and PC-3 human prostate cancer cell lines express androgen receptor: Implications for the androgen receptor functions and regulation. FEBS Lett 2006; 580: 2294300.

30. Renis M, Calandra L, Scifo C, et al. Response of cell cycle/stress-related protein expression and DNA damage upon treatment of $\mathrm{CaCO} 2$ cells with anthocyanins. $\mathrm{Br}$ J Nutr 2008; 100: 27-35. 